\title{
The Lvov-Warsaw School and Its Future
}

\author{
Angel Garrido $^{1, *}$ and Piedad Yuste ${ }^{2}$ \\ 1 Department of Fundamental Mathematics, Faculty of Sciences, National University of Distance \\ Learning (UNED), 28040 Madrid, Spain \\ 2 Department of Philosophy, Faculty of Philosophy, National University of Distance Learning (UNED), \\ 28040 Madrid, Spain; pyuste@fsof.uned.es \\ * Correspondence: agarrido@mat.uned.es; Tel.: +34-91-398-7237
}

Academic Editors: Humberto Bustince and Urszula Wybraniec-Skardowska

Received: 29 February 2016; Accepted: 8 April 2016; Published: 11 April 2016

The Lvov-Warsaw School (L-WS) was the most important movement in the history of Polish philosophy, and certainly prominent in the general history of philosophy, and 20th century logics and mathematics in particular. It concerns very deep fundamental problems, such as "future contingents", under a new interpretation. This particular and difficult problem is also connected to Eastern philosophy, and was treated by Aristotle in Peri hermeneias (De Interpretatione, in Latin) [1].

Future contingents are contingent statements about a possible, but not certain, state of affairs in the future, i.e., these statements are not necessarily true, nor necessarily false. The difficulty arises when trying to assign a truth value (true/false) to such a statement. This is exemplified by Aristotle's Sea Battle Paradox (Peri hermeneias, Ch. IX). What truth value should be assigned to the proposition "tomorrow there will be a sea-battle"? If it is taken to be true, or false, the event is not contingent anymore. The Future Contingent problem became central for scholasticism in medieval times, studied by William of Ockham, Jan Duns Scotus, Peter de Rivo, or Richard of Lavenham, among others. These authors were interested in its relationship with determinism and the theological issue of Divine Foreknowledge. The issue received great attention from Spanish Jesuits, Luis de Molina and Francisco Suarez, and even the great polymath G. W. Leibniz dedicated time to it. However, darker times for logics then followed. Up until the 19th century, the same questions kept arising under different guises, thanks to philosophers and mathematicians such as George Cantor, Augustus De Morgan, George Boole and Gottlob Frege. It was then that the new set theory was born. This theory, today called "classic" or "crisp", also had its declared enemies at the time, such as Henri Poincaré from France, or Leopold Kronecker from Germany, who although having been the mentor of George Cantor in Berlin, turned later to fight against him intellectually. His opposition hindered Cantor's academic progress and thus the expansion of novel ideas.

These new ideas were developed in parallel to a true lineage, from masters to disciples that together conforms a school of thought across generations, like rivers and tributaries. Starting from Bernardo Bolzano, intellectual heir of G. W. Leibniz, and followed by Franz Brentano, having a great influence on his subsequent disciples. Among Brentano's students, there is one of special interest to us; the Polish philosopher, Kazimierz Twardowski, who shared many characteristics with his teacher: love for precision and clarity of ideas, charisma among those who treated him well, and preference for the spoken over the written word. From his chair in the University of Lvov (1895), many of the ideas of Franz Brentano were spread, and new followers added ideas of their own. Thus, a circle of thinkers keenly interested in renewing philosophical studies, especially from the logical point of view, was formed. This was the so-called Lvov-Warsaw School (L-WS, by acronym). In a certain sense, this served a similar function to (but very independent from) the Vienna Circle (Wiener Kreis), or later the Berlin Circle, thanks to its singular characteristics. Its members took the logical-philosophical and mathematical studies from Poland to the forefront of global world research. This was principally 
during the "interbellum" period between the two World Wars, i.e., from 1918 to 1939. This blooming period was then dramatically interrupted by the Second World War.

Many notable individuals belonged to this group of philosophers and logicians, let us just cite Jan Lukasiewicz, Stanisław Leśniewski, Kazimierz Ajdukiewicz, Tadeusz Kotarbiński, Mordechai Wajsberg, Alfred Tarski (worldwide recognized for his Semantic Theory of Truth), Jerzy Słupecki, or Andrzej Mostowski. We must also remember Jan Woleński (as vindicator of the L-WS memory), Helena Rasiowa, Roman Sikorski, and many others. Then, a powerful mathematical group was developed, with outstanding members such as Stefan Banach (father of Functional Analysis), Hugo Steinhaus, Otto Nikodym, Stanisław Ulam, Kazimierz Kuratowski, Stanislaw Saks, etc.

A famous computer scientist, and continuer of L-WS, Prof. Zdzislaw Pawlak, proposed an interesting alternative to Zadeh's conception of fuzzy sets. Pawlak was indeed the creator of the complementary theory of Rough Sets, proposed in 1982, and he was the founder of a new and very powerful Polish School of Artificial Intelligence, being one of the most remarkable pioneers in computer science with worldwide influence. The very fundamental concept behind Rough Set Theory is the approximation of lower and upper spaces of a set, i.e., to improve the approximation of spaces. It supposed a different interpretation to the problem of uncertainty. There are many studies done by students of the Polish school who worked with Z. Pawlak. In particular, we can mention Ewa Orłowska, Andrzej Skowron, Roman Słowiński, Zbigniew Suraj, or Urszula Wybraniec-Skardowska and her pupils in Opole.

Other highly valued logicians have carried out deep analyses of, such as Bertrand Russell, Etienne E. Kerre from Ghent (Belgium), Roman Murawski (Poland), the Azeri Max Black [2], the German-American philosopher, Nicholas Rescher, and in Germany, Dieter Klaua, Siegfried Gottwald, or Hans-Jürgen Zimmerman. Also from Romania, the great figure of Grigore Moisil, and his intellectual descendants: Gheorge Georgescu, Solomon Marcus, and Afrodita Iorgulescu.

Among L-WS members, one of the most interesting representatives is Jan Łukasiewicz [3-22], the father of many-valued logic, in which Fuzzy Logic is rooted [23-28]. Jan Łukasiewicz began to teach at the University of Lvov, and then at Warsaw, but after 1944 was forced to continue in Dublin until his death in 1956. However, Lukasiewicz's writings fell for a long time into oblivion until they were recovered thanks to the interest of an Azeri engineer and mathematician, Lotfi Asker Zadeh, who had studied in Tehran and then at the Massachusetts Institute of Technology (MIT), before becoming a professor at the University of California, Berkeley.

Lofti Zadeh (through his friend, the American logician, Stephen Cole Kleene) discovered the potential utility of these ideas in 1965, obtaining a generalized version of the classical theory of sets (also called 'crisp sets'). This new paradigm is now called the "Fuzzy Set Theory" (FST, by acronym). Zadeh extended these ideas later to logics, creating "Fuzzy Logic" [29-31]. This was not without opposition, because a great number of critics, sometimes malicious and misinformed, bombarded him with the "heavy artillery" (the Italian patriarch of Statistics, Bruno de Finetti, for instance).

However, over time, it was in Eastern countries where these ideas came to fruition, creating a powerful technological "boom", with new techniques based on "fuzzy" concepts. This trend was particularly strong in Japan, and then it spread to other countries, such as South Korea, China or India. Following these ideas, further applications came to Western countries, both European and American. Today, the field fosters brilliant studies both from a mathematical point of view and with its philosophical implications.

We have gathered here many of the leading specialists in these topics. It offers great novelty and is of profound interest to the advancement of science, especially logic and artificial intelligence, because of the deep connections between mathematics, philosophy and computer science (with important applications, for example, in linguistics, medicine, economics or robotics).

We believe it is essential to continue spreading information on what is one of the most interesting and promising fields of knowledge. 


\section{References}

1. Ross, W.D.; Smith, J.A. The Works of Aristotle; Oxford University Press: Oxford, UK, 1928.

2. Black, M. Vagueness: An exercise in logical analysis. Philos. Sci. 1937, 4, 427-455. [CrossRef]

3. Klaua, D. Allgemeine Mengenlehre: Ein Fundament der Mathematik; Akademie-Verlag: Leipzig, Germany, 1964.

4. $\quad$ Łukasiewicz, J. Selected Works; Borkowski, L., Ed.; North Holland C. Publ. Co.: Amsterdam, The Netherlands, 1970.

5. Mostowski, A. L'oeuvre scientifique de Jan Łukasiewicz dans le domaine de la logique mathématique. Fundam. Math. 1957, 44, 1-11.

6. Prior, A.N. Three-valued logic and future contingents. Philos. Quart. 1953, 3, 317-326. [CrossRef]

7. Prior, A.N. Lukasiewicz's contribution to logic. In Philosophy in the Mid-Century, a Survey; Klibański, R., Ed.; Logic and Philosophy of Science: Firenze, Italy, 1958; Volume I, pp. 53-55.

8. Trzęsicki, K. Łukasiewicz on Philosophy and determinism. In Polish Scientific Philosophy; Coniglione, F., Poli, R., Woleński, J., Eds.; Rodopi Verlag: Amsterdam, The Netherlands, 1993; pp. 251-297.

9. Borkowski, L.; Słupecki, J. The Logical Works of J. Łukasiewicz. Stud. Logica 1958, 8, 7-56.

10. Coniglione, F. Filosofia e scienza in Jan Łukasiewicz. Epistemologia 1994, 17, 73-100.

11. Domínguez Prieto, P. Indeterminación y Verdad: La polivalencia lógica en la Escuela de Lvov-Varsovia; Nossa y Jara Editores: Móstoles, Spain, 1995.

12. Garrido, A. Special functions in Fuzzy Analysis. Opusc. Math. 2006, 26, 457-464.

13. Garrido, A. Searching the arcane origins of Fuzzy Logic. Brain 2011, 2, 51-57.

14. Garrido, A. Filosofía y Matemáticas de la Vaguedad y de la Incertidumbre. Ph.D. Thesis, Universidad Nacional de Educación a Distancia (UNED), Madrid, Spain, 2013.

15. Garrido, A. Lógicas de Nuestro Tiempo; Dykinson Editorial Group: Madrid, Spain, 2014.

16. Garrido, A. Lógica Aplicada. Vaguedad e Incertidumbre; Dykinson Editorial Group: Madrid, Spain, 2014.

17. Garrido, A. Lógica Matemática e Inteligencia Artificial; Dykinson Editorial Group: Madrid, Spain, 2015.

18. Garrido, A. Controversias del pensamiento; Dykinson Editorial Group: Madrid, Spain, 2016.

19. Woleński, J. Logic and Philosophy in the Lvov-Warsaw School; Kluwer Academic Publishers: Dordrecht, The Netherlands, 1989.

20. Smith, B. Austrian Philosophy: The Legacy of Franz Brentano; Open Court Publishing Co.: Chicago, IL, USA, 1994.

21. Pawlak, Z. Rough Sets. Intern. J. Comp. Inform. Sc. 1982, 11, 341-356. [CrossRef]

22. Wybraniec-Skardowska, U. Polish Logic: Some Lines from a Personal Perspective; Publications of Institute for Logic, Language and Computation: Amsterdam, The Netherlands, 2009.

23. Kleene, S.C. Introduction to Metamathematics; North-Holland Publ. Co.: Amsterdam, The Netherlands, 1952.

24. Gottwald, S. A Treatise on Many-Valued Logics; Research Studies Press Ltd.: Hertfordshire, UK, 2001.

25. Rasiowa, H. An Algebraic Approach to Non-Classical Logics; North-Holland Publ. Co.: Amsterdam, The Netherlands, 1974.

26. Zinoviev, A.A. Philosophical Problems of Many-Valued Logic; Reidel Verlag: Dordrecht, The Netherlands, 1963.

27. Rosser, J.B.; Turquette, A.R. Many-Valued Logics; North-Holland Publ. Co.: Amsterdam, The Netherlands, 1952.

28. Rescher, N. Many-Valued Logic; McGraw-Hill Inc.: New York, NY, USA, 1969.

29. Trillas, E. Lotfi A. Zadeh: On the man and his work. Sci. Iran. 2011, 18, 574-579. [CrossRef]

30. Zadeh, L.A. Fuzzy Sets. Inf. Control 1965, 8, 338-353. [CrossRef]

31. Zadeh, L.A. Fuzzy Logic and approximate reasoning. Synthese 1975, 30, 407-428. [CrossRef]

(C) 2016 by the authors; licensee MDPI, Basel, Switzerland. This article is an open access article distributed under the terms and conditions of the Creative Commons Attribution (CC-BY) license (http://creativecommons.org/licenses/by/4.0/). 